\title{
The Effect of Non Performing Financing and Bank Indonesia Sharia Certificates (SBIS) on Financing of Natural Uncertainty Contract (NUC) with Third Party Fund (DPK) as a Moderating Variable
}

Tri Utami ${ }^{1 \bowtie}$, Dila Angraini ${ }^{2}$, Dea Annisa ${ }^{3}$, Wiwit Irawati ${ }^{4}$

${ }^{1}$ Bachelor of Accounting Study Program, Faculty of Economics, Universitas Pamulang, Indonesia

${ }^{2}$ Bachelor of Accounting Study Program, Faculty of Economics, Universitas Pamulang, Indonesia

${ }^{3}$ Bachelor of Accounting Study Program, Faculty of Economics, Universitas Pamulang, Indonesia

${ }^{4}$ Bachelor of Accounting Study Program, Faculty of Economics, Universitas Pamulang, Indonesia

\section{Article Information}

Article history:

Accepted: September 2020

Approved: January 2021

Published: March 2021

Keywords:

Natural Uncertainty Contract

(NUC) Contract Financing,

Third-Party Funds (DPK),

Non-Performing Financing,

Certificate of Bank Indonesia

Syariah (SBIS)

\begin{abstract}
This type of research is quantitative associative and the data used is the annual data on the financial statements of Islamic Commercial Banks registered with the Financial Services Authority for the 2015-2018 period, totalling 14 BUS. The sample is determined using a purposive sampling method. The number of Islamic Commercial Banks studied was 8 with a research period of 4 years to obtain 32 samples. This study uses the Multiple Linear Regression method, using the help of the EViews 9 program. From the results of hypothesis testing, it is found that the variable financing problems and SBIS have a joint effect on NUC. However, partially problematic financing has no effect on NUC and SBIS has a positive effect on NUC. With TPF as a moderating variable, the test results using the Moderated Regression Analysis technique show that TPF does not moderate the effect of non-performing financing (NPF) on NUC but TPF can moderate the effect of the SBIS variable on NUC.
\end{abstract}

How to Cite: Utami, T., Angraini, D., Annisa, D., \& Irawati, W. (2021). The Effect of Non Performing Financing and on Financing of Natural Uncertainty Contract (NUC) with Third Party Fund (DPK) as a Moderating Variable. Jurnal Penelitan Ekonomi dan Bisnis, 6(1), 35-44. doi: https://doi.org/10.33633/jpeb.v6i1.4262 


\section{INTRODUCTION}

In its development, Islamic Banking has progressed quite rapidly. Islamic banking is a bank that implements financial transactions following the values and principles of sharia in Islam. Currently, Islamic banking in Indonesia has developed and is progressing well. We can prove this with the increasing number of offices of Islamic financial institutions in Indonesia. In 2018, there were 14 Islamic Commercial Banks with a total of 1,875 offices, 20 Sharia Business Units with 354 offices, and a BPRS with 167 banks and 495 offices. (Otoritas Jasa Keuangan, 2018).

The objective of Islamic banking is to support the implementation of national development, such as providing support to the real sector through financing according to sharia principles and real transactions (intermediation function), in the context of equitable distribution of people's welfare. Financing as an effort by financial institutions to move the real sector has received high attention from Islamic banking. In channeling financing, Islamic banks can provide various types of contracts, namely: mudaraba, musyarakah, murabahah, salam, istishna', ijarah, and qardh (Wardiantika, 2014)

In operation, in Islamic commercial banks, there are two concepts in the use of a contract, the first is the concept of a natural certainty contract (NCC), the concept of a natural certainty contract is a concept in which there are two parties who exchange their assets so that the object of exchange is good. goods or services must also be determined at the beginning of the contract with certainty, in terms of quantity, quality, price, and time of delivery (Karim, 2014)

These contracts offer a fixed and definite return. The contract in the contract is a sale and purchase contract, which uses the following contracts: Murabahah, Salam, and Istishna. Meanwhile, the lease agreement is Ijarah and IMBT. As well as Qard is used in social transactions. And the second concept is the natural uncertainty contract (NUC), which is a concept in which the transaction mixes the assets of the parties involved (both real assets and financial assets) into a single unit and takes the risk together for profit. In the NUC concept, the advantages and disadvantages are shared. Therefore, this contract does not provide certainty of income (return), both in terms of quantity and time. Included in this contract are investment contracts that do not offer fixed and definite returns. In Islamic banking, the contract is in the concept of the NUC (profit sharing), namely: Musharaka and Mudharabah (Karim, 2014)

These two types of financing, namely Musharaka and Mudharabah, are financing following the main characteristic of Islamic banking, namely profit-sharing-based financing, but in its development, this natural uncertainty contract financing has not yet dominated sharia reform. As of December 2018, the financing that still dominates Islamic banking is Murabahah financing or financing in terms of buying and selling. Therefore, Islamic banking must continue to increase the distribution of funds on the profit-sharing principle where the Islamic banking policy in determining the nominal amount of financing needs to consider internal factors that can pose risks so that Islamic banking can also minimize risk.

In Figure 1, you can see that there are two profit-sharing contracts in the natural uncertainty contract concept used in Islamic banking, namely the Mudharabah contract and the Musyarakah contract. Judging from the graph, the musyarakah contract has always increased from 2015 to 2018 . While the mudharabah contract has increased gradually from 2015 to 2017 and in 2018 has decreased.

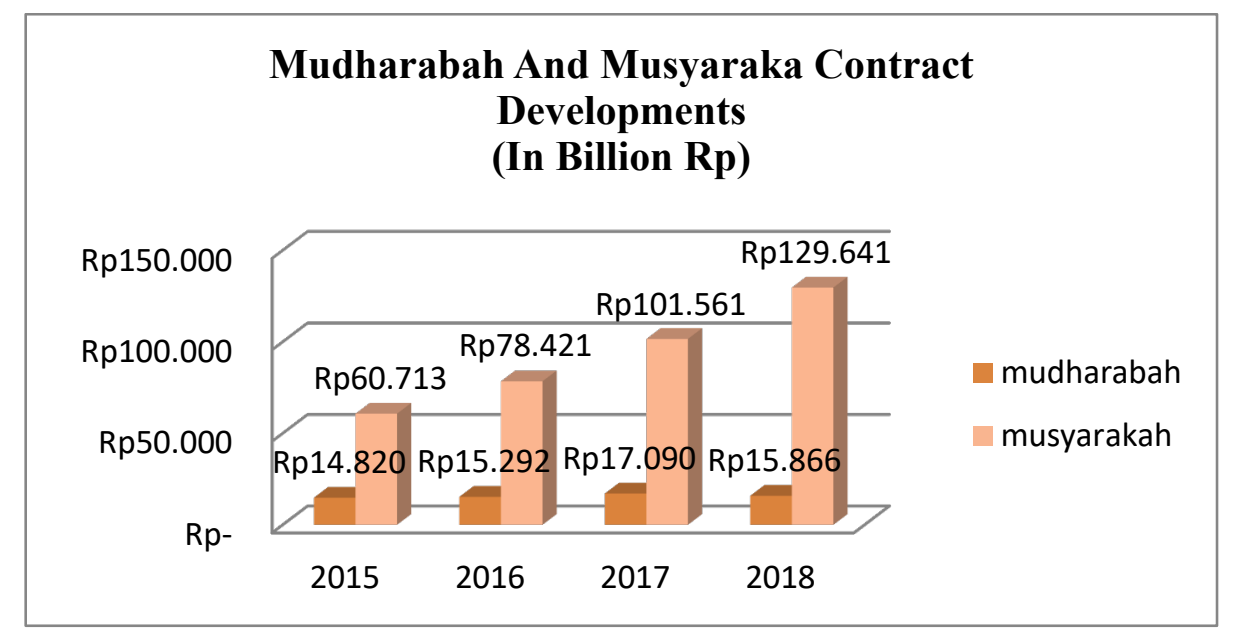

Figure1. Mudharabah and Musyaraka Contract Developments Source: OJK, 2019 
Tri Utami, Dila Angraini, Dea Annisa, and Wiwit Irawati: The Effect of Non Performing Financing and Bank Indonesia Sharia Certificates (SBIS) on Financing of Natural Uncertainty Contract (NUC) with Third Party Fund (DPK) as a Moderating Variable

Profit-sharing financing with the mudharabah contract is still far behind from the musyarakah contract, so it is necessary to examine what factors can affect the amount of financing using the NUC contract to increase the distribution of funds in financing with the profit-sharing principle where the bank's policy is to determine the amount of disbursement of funds in financing for the results also need to consider various factors so that the possible risks that occur can be avoided or minimized. Mudharabah and musyarakah financing has differences in the distribution of capital and business management, as well as profit sharing. If mudharabah financing, the bank contributes $100 \%$ of the capital, while the customer only manages the business. Profit-sharing is based on the amount of capital contributed. For musharaka financing, the bank and the customer both contribute capital and manage the business, usually $60 \%$ : 40\%. Profit-sharing is also based on the amount of capital included in the business (Permata, 2014).

The ability to channel funds is influenced by several factors that can be measured from the internal and external sides of a bank. From the internal side, one of them is influenced by the ability of banks to collect public funds (Husaeni, 2017). Third-Party Funds (DPK) are the main reason for a bank institution to maintain its liquidity level. Third-party funds are a very important source of funds for Islamic banks because these funds will be channeled in the form of financing to people who are short of funds (Umarih, 2020). Previous research was conducted by Pradesyah, (2015) who tested the influence of NPF and DPK on Mudharabah financing. Meanwhile, research conducted by (Angraini \& Sumantri, 2019) with partial NPF results has no effect on profit-sharing financing, while TPF has a positive effect on profit-sharing financing. In a study conducted by (Badruzaman, 2009), it was found that the Bank Indonesia Wadiah Certificate had an effect on mudharabah financing.

Table 1. Composition of Non-Performing Financing, SBIS, and TPF in Islamic Banking in Indonesia for the Period 2015-2018

\begin{tabular}{c|c|c|c}
\hline Period & $\begin{array}{c}\text { DPK } \\
\text { (Billion Rp) }\end{array}$ & $\begin{array}{c}\text { Non-Performing } \\
\text { Financing / NPF (\%) }\end{array}$ & $\begin{array}{c}\text { SBIS } \\
\text { (Billion Rp) }\end{array}$ \\
\hline 2015 & 174.895 & 4,84 & 25.797 \\
\hline 2016 & 206.407 & 4,42 & 34.755 \\
\hline 2017 & 238.393 & 4,76 & 41.162 \\
\hline 2018 & 257.606 & 3,26 & 37.800 \\
\hline
\end{tabular}

Source: Sharia Banking Statistics (SPS) December 2018, Processed

In table 1, it can be seen that Third Party Funds have increased each year, namely Rp. 174,895 billion in 2015 and then increased in 2016 by Rp. 206,407 billion and in 2017 it increased by $13.41 \%$ to Rp. 238,393 billion and increased again by $7.45 \%$ in 2018 to IDR 257,606 billion. In problem financing, it fluctuates where in 2015 the percentage was $4.84 \%$, in 2016 it decreased $0.42 \%$ to $4.42 \%$ and in 2017 it increased by $0.34 \%$ to $4.76 \%$, and in 2018 decreased to $3.26 \%$. The data also fluctuates in SBIS, namely, in 2015 the number of SBIS was IDR 25,797 billion, in 2016 it increased to IDR 34,755 billion, and in 2017 SBIS increased to IDR 41,162 billion, and in 2018 SBIS decreased to IDR 37,800 billion.

There are several results from previous studies, including The variable Third Party Funds (DPK) has an effect on Mudharabah and Musyarakah Financing (Untari, 2017). The variable of Third Party Funds (DPK) has an effect on profit-sharing financing (Gumilarty, 2016). The results of these two studies imply that the greater, the third-party funds collected by Islamic banks, the greater the amount of revenue sharing financing distributed. The SBIS variable in previous research, namely (Gumilarty, 2016) research, the placement of funds in SBIS has an effect on profit-sharing financing. (Nurbaiti, 2017) Non-Performing Financing (NPF) has an effect on profit-sharing financing. Whereas in Robiyah's (2016) research, NPF has an effect on mudharabah financing in a positive direction. Based on differences in the results of previous studies, this study takes the NPF and SBIS variables as independent variables with DPK as a moderating variable towards NUC.

According to (Karim, 2014) Mixed theory is a theory that discusses how contracts are used in transactions or products in Islamic banking. In this type of contract, the transacting parties mix their assets, both real assets, and financing assets, into one unit, and then assume the risk together for profit. Here, profits and losses are shared according to the agreement at the beginning of the contract.

In this theory, there are two pillars, namely: Mixing Object consists of 'Ayn (real assets) in the form of goods and services and Dayn (financial assets) in the form of money and securities. From these two objects, three types of mixing can be identified, namely Mixing real assets ('Ayn) with real assets ('Ayn) and Mixing real assets ('Ayn) with financial assets (Dayn). Mixing financial assets (Dayn) with financial assets (Dayn) consist of 'Ayn (real assets) in the 
form of goods and services and Dayn (financial assets) in the form of money and securities. From these two objects, three types of mixing can be identified, namely: (1) Mixing real assets ('Ayn) with real assets ('Ayn), (2) Mixing real assets ('Ayn) with financial assets (Dayn), and (3) Mixing financial assets (Dayn) with financial assets (Dayn). The second is Mixing Time. In terms of time, this theory is divided into two times of submission, namely Naqdan (Immediate delivery), namely delivery right away, and Ghairunaqdan (Deferred delivery) namely later delivery.

Natural Uncertainty Contract (NUC) is a contract or contract with a business that does not provide certainty of income (return), both in terms of quantity and time. The income level can be positive, negative, or zero. Included in this contract are investment contracts, this contract does not offer a fixed and definite return. In this type of contract, the transacting parties mix their assets (both real assets and financial assets) into a single unit and share the risk for profit. In this contract, the profits and losses are shared (Karim, 2014). In this case, according to (Soemitra, 2019), the financing of the NUC contract includes the financing of the Musyarakah and Muudharabah contracts.

Law No. 21, 2008 concerning Islamic banking states that, "Deposits are funds entrusted by customers to Sharia Banks and/or laws based on Akadwadi'ah or other contracts that do not conflict with sharia principles in the form of Giro, Savings, or other forms equivalent". Non-Performing Financing (NPF) is a ratio that compares the level of nonperforming financing (qualified financing) to the total financing provided (Bank Indonesia, 2018). Based on BI Regulation Number 15/2 / PBI / 2013, banks are considered to have potential difficulties that endanger their business continuity if one of them has a net non-performing loan / non-performing financing ratio of more than $5 \%$ of total credit (Utami, 2018). Based on Bank Indonesia Regulation Number 10/11 / PBI concerning Bank Indonesia Sharia Certificates are short-term securities based on sharia principles in rupiah currency issued by Bank Indonesia. According to (Arifin, 2009). What is meant by Sharia Bank Indonesia Certificate (SBIS) is a certificate issued by Bank Indonesia as evidence of short-term deposits of funds. SBIS is a monetary instrument that conforms to the principles of Islamic banks created in the context of implementing monetary control.

Figure 2 explains partially through $\mathrm{H} 2$ and $\mathrm{H} 3$ the effect of each NPF and SBIS variable on the NUC variable, and also explains simultaneously through $\mathrm{H} 1$ the effect between the NPF and SBIS variables on the Y variable. and H5 the effect of the DPK variable as moderating SBIS on NUC. The following is a picture description of the framework in this study:

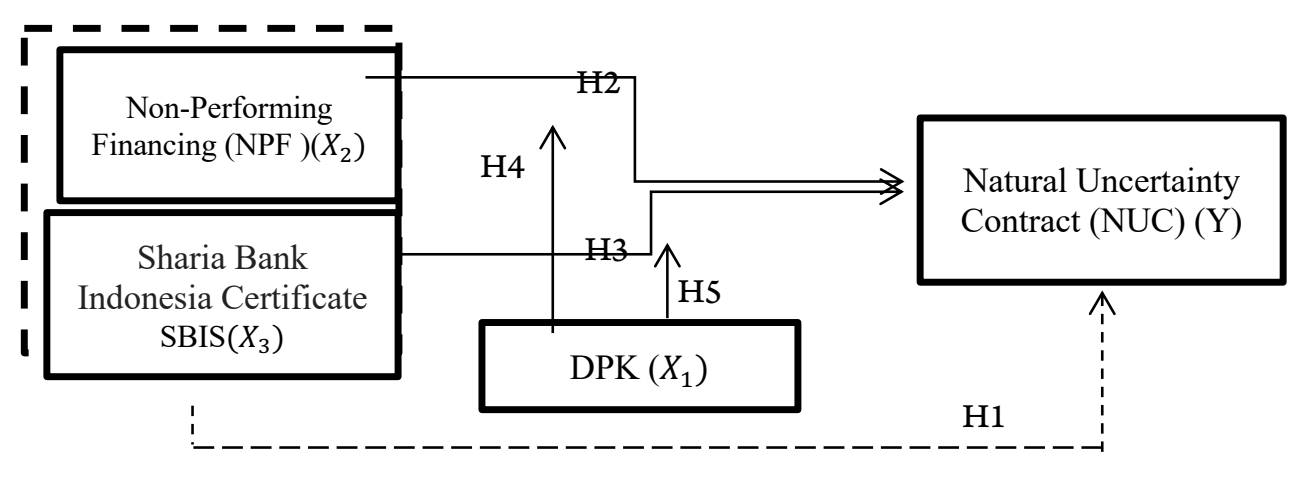

Figure 2. Research Framework

\section{METHOD}

In this research, the type of research used is quantitative research. Operational data used in this study uses panel data. According to Ghozali (2017) Panel data is a combination of time series data and cross-section data. The population in this study were 14 Islamic commercial banks registered with the OJK for the 2015-2018 period. The technique used in determining the sample is purposive sampling with the following criteria: 1) Islamic Commercial Banks registered with the Financial Services Authority. 2) Islamic Commercial Banks in the financial statements for the 2015 - 2018 period, there are variables used by researchers. 3) Islamic commercial banks that regularly publish annual financial reports during the observation period, namely 2015 to 2018, and in the processing there are 2 outliers of data so that 32 sample units are obtained consisting of 8 Islamic commercial banks with 4 research periods. year. The data analysis technique used in this study is the Multiple Linear Regression analysis technique using the EVIEWS 9 program and Microsoft Excel 2010. 
Tri Utami, Dila Angraini, Dea Annisa, and Wiwit Irawati: The Effect of Non Performing Financing and Bank Indonesia Sharia Certificates (SBIS) on Financing of Natural Uncertainty Contract (NUC) with Third Party Fund (DPK) as a Moderating Variable

According to Sugiyono (2017), the dependent variable is the variable that is influenced or becomes the result because there are independent variables. The dependent variable in this study is the Natural Uncertainty Contract which is a contract or contract in a business that does not provide certainty of income (return), both in terms of quantity and time. The income level can be positive, negative, or zero. Included in the Natural Uncertainty Contract financing variable are Mudharabah financing and Musyarakah financing. So to determine the financing of the NUC contract using the formula:

\section{Natural Certanty Contact $($ NUC $)=$ Musyarakah Financing + Mudharabah Financing}

The independent variable affects the emergence of a dependent variable. The independent variables used in this study are non-performing financing (NPF), and Bank Indonesia Syariah certificates. Here is the formula for measuring the NPF level:

$$
N P F=\left(\frac{\text { Bad Financing }}{\text { Total Financing }} \times 100 \%\right)
$$

Bank Indonesia publishes monetary instruments based on sharia principles and can be used by Islamic banks to overcome excess liquidity levels. The following formula can be used :

\section{SBIS $=\mathrm{LN}$ (Amount of Fund Placement in SBIS) \\ Source: PBI No. 10/11/PBI/2008}

According to Sugiyono (2017), the moderating variable is a variable that affects (strengthens or weakens) the direct relationship between the independent variable and the dependent variable. The moderating variable is a type of variable that has an effect on the nature or direction of the relationship between variables. The nature or direction of the relationship between the independent variables and the dependent variables may be positive or negative, in this case depending on the moderating variable. The moderating variable $(\mathrm{z})$ in this study is third-party funds. In the calculation, you can use the following formula (Soemitra, 2019):

\section{Third-Party Fund = Giro Wadi'ah + Saving Wadi'ah + Saving Mudharabah + Deposit Mudharabah}

Because there is a moderating variable, one of the hypothesis testing in this study was carried out using Moderated Regression Analysis (MRA). MRA is a special tool in multiple linear regression testing, which in the regression equation contains an element of interaction (Ghozali, 2012).

\section{RESULT AND DISCUSSION}

The first step in this research is descriptive statistical analysis. Based on descriptive statistical analysis, the following are the results of descriptive statistical calculations:

Table 2. Statistik Deskriptif

\begin{tabular}{l|c|c|c|c|c}
\hline & NUC & C & NPF & SBIS & DPK \\
\hline Mean & 2995642. & 1.000000 & 2.914375 & 27.55875 & 27.30656 \\
\hline Median & 2257878. & 1.000000 & 3.005000 & 27.69500 & 27.22000 \\
\hline Maximum & 8040485. & 1.000000 & 4.970000 & 29.39000 & 29.81000 \\
\hline Minimum & 57611.00 & 1.000000 & 0.040000 & 24.29000 & 24.34000 \\
\hline Std. Dev. & 2362751. & 0.000000 & 1.525036 & 1.315821 & 1.498833 \\
\hline Observations & 32 & 32 & 32 & 32 & 32 \\
\hline
\end{tabular}

Source: output EVIEWS 9, 2020

From the data above, it can be seen that the average value of the NUC is 2,995,642 with a standard deviation value of 2,362,751. The average value of TPF was 27.31 with a standard deviation of 1.49 . The average value of Troubled Financing is 2.91 with a standard deviation of 1.52 . The average value of LN SBIS was 27.56 with a standard 
deviation of 1.31. A standard deviation value that is smaller than the average value indicates that the data is representative of the population. After that, panel data regression analysis was carried out for 32 observation data by performing the Chow test, Hausman test, and Lagrange Multiplier (LM) test. From the three models, the model is chosen between the common effect model, the fixed-effect model, and the random effect model, so after testing the most appropriate model is the random effect model. Furthermore, the classical assumption test analysis is carried out by performing the normality test, non-multicollinearity test, non-heteroscedasticity test, and non-autocorrelation test. From the test results that have been carried out, the observational data has no constraints on the classical assumption test, here are the results

From the results of the normality test, it is known that the prob value is $0.474522>0.05$, it can be concluded that the data is normally distributed.

Table 3. Normality Test

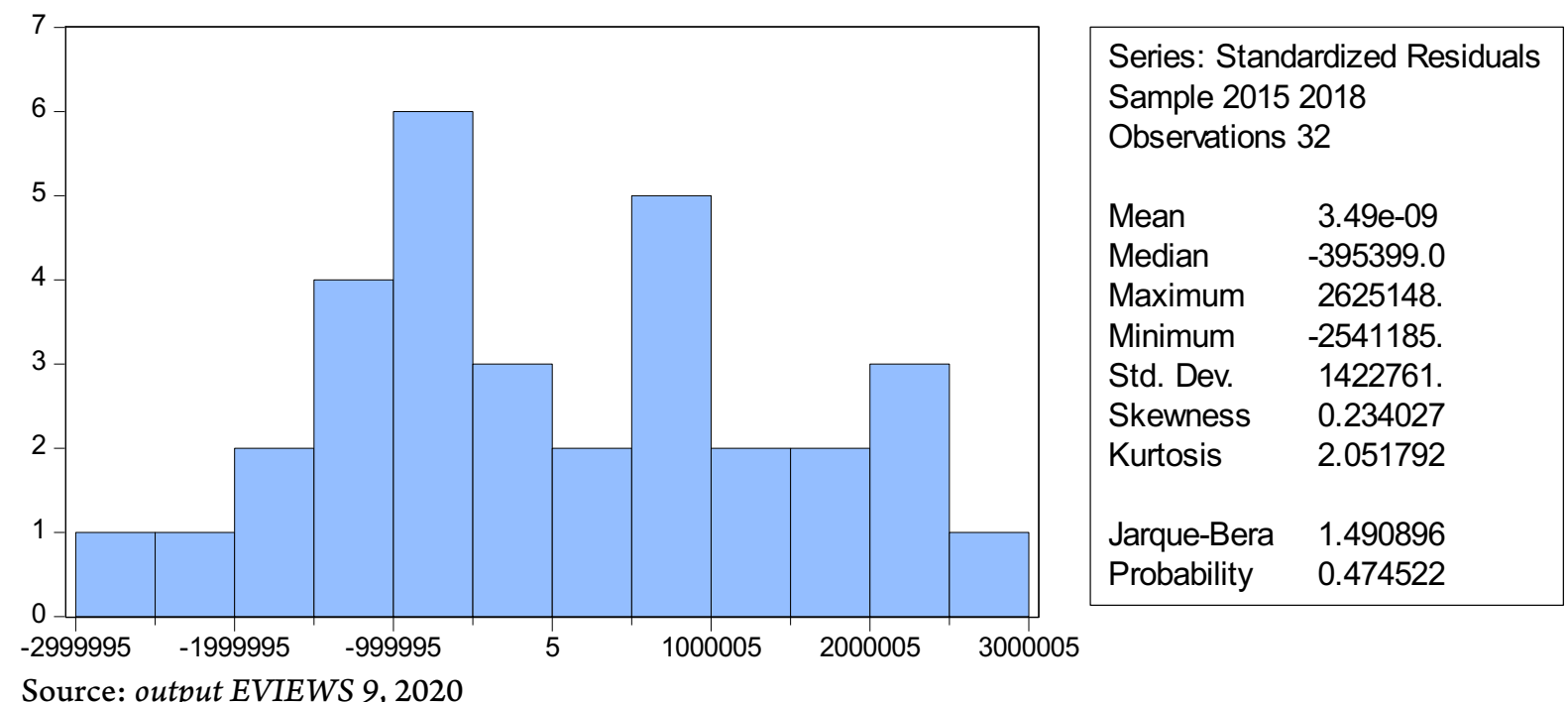

Table 4. Heteroscedasticity Test

\begin{tabular}{c|c|c|c|c}
\hline Variable & Coefficient & Std. Error & t-Statistic & Prob. \\
\hline C & 22985055 & 10501138 & 2.188816 & 0.0401 \\
\hline NPF & 165918.8 & 98467.60 & 1.685009 & 0.1068 \\
\hline SBIS & -221306.5 & 308698.7 & -0.716901 & 0.4813 \\
\hline DPK & -584499.4 & 351046.1 & -1.665022 & 0.1108 \\
\hline
\end{tabular}

Source: output EVIEWS 9, 2020

With the test results obtained the prob value of each independent variable $>0.05$, it can be concluded that there is no heteroskedasticity problem.

Table 5. Multicollinearity Test

\begin{tabular}{c|c|c|c}
\hline & NPF & SBIS & DPK \\
\hline NPF & 1.000000 & -0.144595 & -0.448570 \\
\hline SBIS & -0.144595 & 1.000000 & 0.480081 \\
\hline DPK & -0.448570 & 0.480081 & 1.000000 \\
\hline
\end{tabular}

Source: output EVIEWS 9, 2020

From the results shown in the table, the correlation value between independent variables and moderating variables is not more than 0.9 , so there is no multicollinearity problem. 
Tri Utami, Dila Angraini, Dea Annisa, and Wiwit Irawati: The Effect of Non Performing Financing and Bank Indonesia Sharia Certificates (SBIS) on Financing of Natural Uncertainty Contract (NUC) with Third Party Fund (DPK) as a Moderating Variable

Table 6. Autokolerasi Test

\begin{tabular}{l|r|l|l}
\hline R-squared & 0.899106 & Mean dependent var & 1409005. \\
\hline Adjusted R-squared & 0.851062 & S.D. dependent var & 1060438. \\
\hline S.E. of regression & 409249.8 & Akaike info criterion & 28.94833 \\
\hline Sum squared resid & $3.52 E+12$ & Schwarz criterion & 29.45217 \\
\hline Log-likelihood & -452.1732 & Hannan-Quinn criter. & 29.11534 \\
\hline F-statistic & 18.71398 & Durbin-Watson stat & 1.941134 \\
\hline Prob(F-statistic) & 0.000000 & &
\end{tabular}

Source: output EVIEWS 9, 2020

From the results of the Durbin Watson value $-2<1.941<2$, there is no autocorrelation problem. The next stage is to test the hypothesis with the following table showing the results of the hypothesis testing:

Table 7. f Test

\begin{tabular}{l|l|l|r}
\hline R-squared & 0.384884 & Mean dependent var & 1221915. \\
\hline Adjusted R-squared & 0.318978 & S.D. dependent var & 1347023. \\
\hline S.E. of regression & 1111618. & Sum squared resid & $3.46 \mathrm{E}+13$ \\
\hline F-statistic & 5.839947 & Durbin-Watson stat & 1.731497 \\
\hline Prob(F-statistic) & 0.003137 & &
\end{tabular}

Source: output EVIEWS 9, 2020

Table 8. t-Test

\begin{tabular}{c|r|r|r|r}
\hline Variable & Coefficient & Std. Error & t-Statistic & \multicolumn{1}{|c}{ Prob. } \\
\hline C & -20393158 & 11027323 & -1.849330 & 0.0750 \\
\hline NPF & -45837.78 & 164542.4 & -0.278577 & 0.7826 \\
\hline SBIS & 1537841. & 393713.0 & 3.905995 & 0.0005 \\
\hline DPK & -690624.6 & 375266.1 & -1.840360 & 0.0763 \\
\hline
\end{tabular}

Source: output EVIEWS 9, 2020

From the results of the MRA stage 1 test, it is known that the NPF variable is an independent, intervening, exogenous, antecedent, or predictor variable (Sugiono, 2017). Shown by the probability value of DPK against the NUC Akad of $0.0001<0.005$ while the value of $\mathrm{DPK}^{*} \mathrm{NPF}$ against the NUC Akad is $0.8415>0.05$.

Table 9. Moderate Regression Analysis Step 1

\begin{tabular}{c|r|r|r|r}
\hline Variable & Coefficient & Std. Error & t-Statistic & \multicolumn{1}{|c|}{ Prob. } \\
\hline C & -49950885 & 12034219 & -4.150737 & 0.0003 \\
\hline NPF & 610119.2 & 2875183. & 0.212202 & 0.8335 \\
\hline DPK & 1935564. & 439138.0 & 4.407645 & 0.0001 \\
\hline DPK*NPF & -21268.97 & 105356.3 & -0.201877 & 0.8415 \\
\hline
\end{tabular}

Source: output EVIEWS 9, 2020

Meanwhile, the results of the second stage MRA analysis showed that the DPK variable moderated the effect of the SBIS variable on the NUC contract with a prob value of $0.0004<0.05$. From the following table, the SBIS and DPK variables partially have an effect on the NUC Akad. With these results, it can be said that TPF is a Quasi Moderator variable(Sugiono, 2017). 
Table 10. Tabel 9. Moderate Regression Analysis Step 2

\begin{tabular}{c|c|c|c|c}
\hline Variable & Coefficient & Std. Error & t-Statistic & Prob. \\
\hline C & $3.50 E+08$ & 99994433 & 3.504248 & 0.0016 \\
\hline SBIS & -13998303 & 3515450. & -3.981938 & 0.0004 \\
\hline DPK & -13311446 & 3791662. & -3.510716 & 0.0015 \\
\hline DPK_SBIS & 532727.3 & 132509.3 & 4.020303 & 0.0004 \\
\hline
\end{tabular}

Source: output EVIEWS 9, 2020

Based on the results of hypothesis testing, the results show that problematic financing and Bank Indonesia Syariah Certificates simultaneously affect the Financing of Natural Uncertainty Contracts (NUC) at Islamic Commercial Banks in Indonesia in 2015-2018. These results are proven by a significance value of $0.000000<0,05$ which means that the independent variables have a simultaneous effect on the dependent variable. The results of this study are in line with research in (Gumilarty, 2016) research that the independent variables of DPK, NPF, ROA, SBIS, and TBHt-1 together have a significant effect on profit-sharing financing (2010-2014 period). And in Robiyah's research (2016) the results of his research show that Third Party Funds (DPK), Non-Performing Financing (NPF), Bank Indonesia Sharia Certificates (SBIS), and Financing to Deposit Ratio (FDR) simultaneously have a significant effect on mudharabah financing in Islamic banking in Indonesia (2012 - 2015 period).

Based on partial hypothesis testing, it is known that problematic financing has no effect on the financing of the Natural Uncertainty Contract (NUC) contract. This result is evidenced by the sig value. 0.261 indicates a significance value greater than the probability value $0.05(0.261>0.05)$. While the value of $\mathrm{t}$ count $=1.145$ and $\mathrm{t}$ table of 2.04841 so that the value of $t$ count $<\mathrm{t}$ table $(1.104653<2.04841)$.

This means that an increase in the ratio of non-performing financing (NPF) owned by a bank is not followed by a decrease in the financing of the NUC contract that the bank will distribute to the public. So that the bank continues to channel third-party funds collected in the bank in the form of financing to the community regardless of the ratio of non-performing financing up or down in each period. The results of this study are supported by(Arfiani \& Mulazid, 2017)with the partial results Non-Performing Financing (NPF) has no significant effect on mudharabah savings and research(Umiyati \& Ana, 2020)with NPF results have no effect on financing in BUS 2011-2015.

Based on partial hypothesis testing, it is known that the Bank Indonesia Syariah Certificate (SBIS) has an effect on the financing of the Natural Uncertainty Contract (NUC) contract. This result is evidenced by the sig value. 0.000 means that the significance value is smaller than the probability value $0.05(0.000<0.05)$. While the value of $\mathrm{t}$-count is 5.506 and $t$ table is 2.04841 , so that the $t$-count $>t$-table $(5.506>2.04841)$.

From the test results, the analysis can be concluded that the SBIS is a monetary financial instrument used by Bank Indonesia following sharia principles. With the existence of SBIS, Islamic banks have several reserves of funds when the bank's financial condition is unstable, or there is a large-scale withdrawal by depositors of funds. This will affect the financing with profit-sharing contracts distributed by the bank. The greater the placement of SBIS funds, the smaller the risk of liquidation problems in Islamic banks. Thus, Islamic banks can still provide financing to the public with several savings funds available in Islamic banks.

Based on testing using the Moderate Regression Analysis technique, the results show that TPF does not moderate the NPF variable against the NUC Akad with a prob value $>0.05$. From the results of this test, it is interpreted that NPF is a deposit of funds from the public which is then managed by the bank in the form of distribution of financing. However, the size of the funds received from the public does not affect the number of ratios from problem financing because the tendency for problem financing to emerging is caused by external factors from the bank, such as the character of customers and the country's economic conditions.

Based on testing using the Moderate Regression Analysis technique, the results show that TPF moderates the SBIS variable to the NUC Akad with a prob value $>0.05$. From the test results, it can be interpreted that TPF, which is the deposit of funds from the public, is the main source of capital for banks in carrying out their operational activities apart from other sources of capital. Meanwhile, SBIS represents short-term deposits from commercial banks to Bank Indonesia, where the allocation of funds deposited depends on how much funds the commercial banks have before deciding the percentage of funds to be allocated for these short-term deposits. However, if the greater the amount of funds stored in the Central Bank, the ratio of funds to be allocated for financing, both buying and selling, leasing, or profit-sharing will be less, therefore SBIS has a negative influence on the NUC Akad. It is in this position that TPF as the main source of bank capital plays a very important role in deciding how much of the funds raised will be allocated for short-term deposits at the Central Bank and to be channeled in the form of financing. 
Tri Utami, Dila Angraini, Dea Annisa, and Wiwit Irawati: The Effect of Non Performing Financing and Bank Indonesia Sharia Certificates (SBIS) on Financing of Natural Uncertainty Contract (NUC) with Third Party Fund (DPK) as a Moderating Variable

\section{CONCLUSION AND RECOMMENDATION}

Based on panel data regression analysis, it is concluded that Variable of Third Party Funds (DPK), NonPerforming Financing, and Bank Indonesia Sharia Certificate (SBIS) simultaneously or together have a positive and significant effect on the Financing of Natural Uncertainty Contracts (NUC) at Islamic Commercial Banks in Indonesia in 2015-2018. Partially problematic financing variables do not have an effect on Natural Uncertainty Contract (NUC) Financing. Partially the variable of Bank Indonesia Sharia Certificate (SBIS) has an influence on the Financing of Natural Uncertainty Contract (NUC) The DPK variable does not moderate the effect of NPF on the NUC. From the results of the MRA stage 1 test, it is known that the NPF variable is an independent, intervening, exogenous, antecedent, or predictor variable. Shown by the probability value of DPK against the NUC. The DPK variable moderates by strengthening the influence of SBIS on the NUC Akad. the DPK variable moderated the effect of the SBIS variable on the NUC contract. From the following table, the SBIS and DPK variables partially have an effect on the NUC Akad. With these results, it can be said that DPK is a Quasi Moderator variable.

\section{REFERENCES}

Angraini, D., \& Sumantri, I. I. (2019). Pengaruh Non Performing Financing, Tingkat Bagi Hasil, Modal Sendiri Dan Dan Dana Pihak Ketiga Terhadap Pembiayaan Bagi Hasil Pada Perbankan Syariah. EkoPreneur.

Arfiani, L. \&. (2017). Analisis Faktor-Faktor yang Mempengaruhi Tingkat Bagi Hasil Simpanan Mudharabah pada Bank Umum Syariah Indonesia Studi Kasus Pada Bank Umum Syariah DI Indonesia Periode 2011-2015. IQTISHADIA Jurnal Ekonomi \& Perbankan Syariah Vol. 4 No. 1.

Arifin, Z. (2009). Dasar-Dasar Manjemen Bank Syariah . Jakarta: Pustaka Alvabet.

Badruzaman, N. (2009). Analisis Pengaruh DPK, Tingkat Bagi Hasil, Sertifikat Wadiah Bank Indonesia Terhadap Pembiayaan Pada bank Syariah di Indonesia.

Ghozali. (2017). Analisis Multivatriate dan Ekonometrika: Teori, Konsep dan Aplikasi dengan menggunakan Eviews 10. Badan Penrbit Universitas Diponegoro.

Ghozali, I. (2012). Aplikasi Analisis Multivariate dengan program IBM SPSS. Yogyakarta: Unuversitas Diponegoro.

Ghozali, I. (2018). Aplikasi Analisis Multivariate dengan Program IBM SPSS 25. Badan Penerbit Universitas Diponegoro: Semarang .

Gumilarty, G. R. (2016). Analisis Pengaruh DPK, NPF, ROA Penempatan Dana Pada SBIS dan Tingkat Bagi Hasil Terhadap pembiayaan Bagi Hasil (Studi Pada Bank Umum Syariah di Indonesia periode 20102014). Vol 5, No. 4 ISSN (online) : 2337-379.

Husaeni, U. A. (2017). Determinan Pembiayaan Pada Bank Pembiayaan Rakyat Syariah di Indonesia . ESENSI http://doi.org/10.15408/ess.v7il.4542.

Karim, A. (2014). Ekonomi Mikro Islami . Rajawali Pers.

Nurbaiti, W. (2017). Pengaruh Dana Pihak Ketiga (DPK), Spread Bagi Hasil, Tingkat Bagi Hasil, Non Performing Financing (NPF) dan Capital Adequancy Ratio (CAR) Pada Bank Umum Syariah periode 2010-2016. Jakarta: Universitas Islam Negeri Syarif Hidayatullah Jakarta.

Permata, R. (2014). Analisis Pengaruh Pembiayaan Mudharabah dan Musyarakah Terhadap Tingkat Profitabilitas (Return On Equity) (Studi Kasus pada Bank Umum Syariah yang Terdaftar di Bank Indonesia Periode 2009-2012). Jurnal Administrasi Bisnis S1 Universitas Sriwijaya.

Pradesyah, R. (2015). Analisis Pengaruh Non Performing Loan, Dana Pihak Ketiga Terhadap Pembiayaan Akad Mudharabah di Bank Syariah di Indonesia.

Soemitra, A. (2019). Bank dan Lembaga Keuangan Syariah .

Sugiyono. (2013). Metode Penelitian Pendidikan Pendekatan Kuantitatif,. Bandung: Alfabeta. 
Sugiyono. (2017). Metode Penelitian Kuantitatif Kualitatif dan RぬD. Bandung: Alfabeta.

Sugiyono. (n.d.). Metode Penelitian Pendidikan Pendekatan Kuantitatif,.

Umarih, D. \&. (2020). The Internal Factor Affecting the Financing of Sharia general Bank in Indonesia . Jurnal Ekonomi Syariah dan Terapan.

Umiyati, U. \&. (2020). Faktor-Faktor yang mempengaruhi Pembiayaan Pada Bank Umum Syariah Devisa Di Indonesia. Jurnal Ekonomu dan Perbankan Syariah.

Untari, L. (2017). Pengaruh Dana Pihak Ketiga (DPK), Kas dan Sertifikat Bank Indonesia Syariah (SBIS) Terhadap Pembiayaan Mudharabah dan Musyarakah pada Perbankan Syariah di Indonesia periode 2010-2014. Universitas Muhammadiyah Surakarta.

Utami, T. (2018). The Influence Of Financing To Deposit Ratio (Fdr), Non Performing Financing (Npf), And Bopo On Zakat Compliance In Islamic Banks In Indonesia Period 2011-2015. Economics and Accounting Journal.

Wardiantika, L. \&. (2014). Pengaruh DPK, CAR dan SWBI Terhadap Pembiayaan Murabahah Pada Bank Umum Syariah. Jurnal Ilmu Manajemen.

www.bi.go.id/ accessed on April 2019

www.ojk.go.id/ accessed on April 2019

www.bcasyariah.co.id/ accessed on April 2019

www.bnisyariah.co.id/ accessed on April 2019

www.brisyariah.co.id/ accessed on April 2019

www.bankmuamalat.co.id/ accessed on April 2019

www. bjbsyariah.co.id/ accessed on April 2019

www.syariahbukopin.co.id/ accessed on April 2019

www.maybanksyariah.co.id/ accessed on April 2019

www.paninbanksyariah.co.id/ accessed on April 2019

www.bankvictoriasyariah.co.id/ accessed on April 2019

www.syariahmandiri.co.id/ accessed on April 2019 